УДК 616.36-008.5

DOI 10.11603/2414-4533.2021.3.12549

СП. Т. МУРАВЙОВ ${ }^{1,2}$, Б. С. ЗАПОРОЖЧЕНКО ${ }^{1,2}$, І. Є. БОРОДАЄВ ${ }^{1,2}$, ХАРХУРІ МАКРЕМ $^{1}$

Одеський національний медичний університет ${ }^{1}$

КНП "ООКМЦ" ООР²

\title{
Особливості передопераційної підготовки хворих на вогнищеві захворювання біліопанкреатодуоденальної зони, що ускладнені механічною жовтяницею
}

\begin{abstract}
Мета роботи: порівняти ефективність існуючих методів підготовки хворих на вогнищеві захворювання біліопанкреатодуоденальної зони, ускладнені синдромом механічної жовтяниці, до панкреатодуоденальної резекції та визначити ефективність застосованих методів біліарної декомпресії.

Матеріали і методи. Проаналізовано результати хірургічного лікування 272 хворих, яким було виконано панкреатодуоденальну резекцію з приводу вогнищевих захворювань біліопанкреатодуоденальної зони, ускладнених розвитком синдрому механічної жовтяниці. До основної групи увійшли 112 пацієнтів, яким підготовку до операції і прогнозування перебігу періопераційного періоду проводили відповідно до розробленого алгоритму. Групи порівняння склали 160 пацієнтів, яким підготовка здійснювалася поза розробленим алгоритмом лише консервативним шляхом.

Результати досліджень та їх обговорення. Завдяки дотриманню застосування розробленого алгоритму детоксикації із застосуванням біліарної декомпресії у хворих основної групи на третій день рівень білірубінемії склав в середньому 185,1 22,4 мкмоль/л,

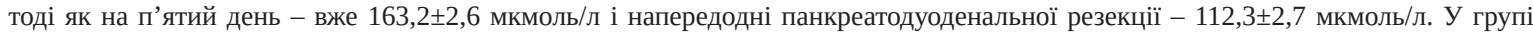
порівняння, де підготовка хворих до радикального операційного втручання здійснювалася лише консервативними заходами без

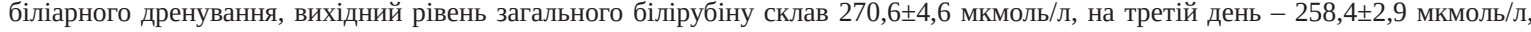
на п’ятий $-222,2 \pm 3,8$ мкмоль/л, а напередодні панкреатодуоденальної резекції - 198,3 $\pm 3,3$ мкмоль/л. Таким чином, в основній групі після декомпресії декремент рівня загального білірубіну склав $\Delta=-59,1$. Натомість у групі порівняння напередодні панкреатодуоденальної резекції декремент рівня загального білірубіну склав $\Delta=-26,7$. Після виконання панкреатодуоденальної резекції

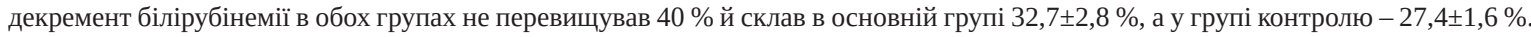
При порівнянні заходів щодо корекції біліарної гіпертензії у хворих основної групи, в усіх підгрупах від початку 3-го дня спостерігалося поступове зниження концентрації білірубіну, більш виражене у пацієнтів, яким виконували черезшкірну черезпечінкову холангіостомію $(164 \pm 18$ мкмоль/л, $<<0,05)$. В середньому на 9 добу визначали достовірне зниження показників загального білірубіну після черезшкірної черезпечінкової холангіостомії на 41,2 \%, лапароскопічної холецистостомії - на 13,6 \% та після пункційної холецистостомії - на 6,6\% (p<0,05).
\end{abstract}

Ключові слова: механічна жовтяниця; біліарне дренування; панкреатодуоденальна резекція; хронічний панкреатит; рак підшлункової залози.

Постановка проблеми і аналіз останніх досліджень та публікацій. Серед найбільш поширених причин розвитку синдрому механічної жовтяниці у хворих із вогнищевими захворюваннями органів панкреатобіліарної зони необхідно виділити хронічний псевдотуморозний (або парадуоденальний) панкреатит, рак головки підшлункової залози (ПЗ), рак Фатерового соска, рак дистального відділу холедоха [1-4].

У більшості випадків це рак ПЗ, що представлений аденокарциномою протокового типу з п'ятирічною виживаністю (за умови первинної резектабельності пухлини і відсутності поширення онкопроцесу) не більше 20 \% [5-8].

Виконання радикального операційного втручання на висоті холемії пов'язане 3 розвитком різних ускладнень більш ніж у 50 \% хворих, а в 15-30 \% випадків взагалі призводить до летального результату [1, 8-10]. Враховуючи вищенаведене, абсолютно обгрунтованим стає дотримання етапності в лікуванні цієї тяжкої категорії пацієнтів: етапу радикального операційного лікування повинен передувати етап підготовки у вигляді максимально можливої компенсації життєвих сил організму шляхом поєднаного застосування інвазивних і неінвазивних способів, спрямованих на зниження проявів холемії [10].

Мета роботи: порівняти існуючі методи підготовки хворих на вогнищеві захворювання біліопанкреатодуоденальної зони, ускладнені синдромом механічної жовтяниці, до панкреатодуоденальної резекції, та визначити ефективність застосованих методів біліарної декомпресії.

Матеріали і методи. В основу дослідження покладено аналіз результатів хірургічного лікування 272 хворих, які перенесли радикальне операційне втручання в обсязі ПДР із приводу злоякісних вогнищевих утворень панкреатодуоденальної зони (218 хворих) і ХПТП (54 пацієнта), ускладнених 


\section{З ДОСВІДУ РОБОТИ}

розвитком синдрому механічної жовтяниці. Чоловіків було 59 (52,7 \%) в основній і 82 (51,3 \%) в групі порівняння, жінок, відповідно, 53 (47,3 \%) і 78 (48,7 \%). Середній вік хворих склав $(49,6 \pm 4,1)$ і $(47,3 \pm 3,3)$ року в основній групі і в групі порівняння відповідно. Верифікацію основного захворювання здійснювали на підставі комплексного обстеження хворих з обов'язковим залученням загальноклінічних, лабораторних та інструментальних методів дослідження УЗД, КТ, МРТ, ФЕГДС.

У хворих основної групи при проведенні генетичного аналізу як додаткові предиктори ймовірності злоякісної трансформації та тяжкого перебігу післяопераційного періоду використо- вували виявлення типоспецифічних мутацій генів (поліморфізмів) PRSS 1 (Arg122His), SPINK 1 (Asn34Ser), TNF (G308A) i CFTR (Phe508del).

Результати досліджень та їх обговорення. Залежно від характеру передопераційної підготовки хворих було розподілено на дві групи: основну групу (112 пацієнтів), хворим якої підготовку до операції і прогнозування перебігу періопераційного періоду проводили відповідно до розробленого алгоритму; і групу порівняння (160 пацієнтів), в якій підготовка здійснювалася поза розробленим алгоритмом за загальноприйнятими на момент планування дослідження правилами (табл. 1).

Таблиця 1. Розподіл хворих залежно від виду передопераційної підготовки

\begin{tabular}{||l|c|c||}
\hline \multirow{2}{*}{\multicolumn{1}{|c|}{ Причина біліарної обструкції }} & \multicolumn{2}{c||}{ Кількість хворих, $\mathrm{n}(\%)$} \\
\cline { 2 - 3 } & $\begin{array}{c}\text { основна група } \\
(\mathrm{n}=112)\end{array}$ & $\begin{array}{c}\text { група порівняння } \\
(\mathrm{n}=160)\end{array}$ \\
\hline Рак головки підшлункової залози (174) & $81(72,3)$ & $93(58,1)$ \\
\hline Рак Фатерового соска (20) & $12(10,7)$ & $8(5,0)$ \\
\hline Рак дистального відділу гепатикохоледоха (24) & $8(7,1)$ & $16(10,0)$ \\
\hline ХПТП (54) & $11(9,8)$ & $43(26,9)$ \\
\hline
\end{tabular}

Хворих госпіталізовували переважно в тяжкому стані з вираженими явищами механічної жовтяниці і початковими проявами синдрому поліорганної недстаточності. Більшість досліджуваних хворих зверталася за медичною допомогою лише через 7-10 і більше днів, а частина взагалі через місяць після прояву зовнішніх ознак біліарної обструкції.

У хворих після визначення величини ризику планованого радикального операційного втручання за розробленою формулою (з урахуванням патоморфологічних параметрів стану хворого) та зважаючи на належність хворого до певного фенотипу (за кількістю і характером виявлених мутованих генів) приймали рішення щодо етапності проведення хірургічного лікування (патент України № 128782; опубл. 10.10.2018; Бюл. №19). Так, якщо ризик виконання ПДР перевищував допустиму межу, хворому як підготовчий етап проводили біліарну декомпресію (основна група, 112 (41,2 \%) хворих). Коли ж ризик не перевищував допустиму межу, вдавалися до виконання радикального операційного втручання в обсязі панкреатодуоденальної резекції.
У 112 хворих (основна група) підготовка до виконання основного операційного втручання полягала в проведенні експрес-детоксикації за розробленою схемою (патент України № 130491; опубл. 10.12.2018; Бюл. № 23). Метод експрес-детоксикації включав проведення біліарної декомпресії катетерами 6F або 9F і процедуру плазмаферезу від 2 до 6 сеансів, при цьому після першого сеансу плазмаферезу призначали перорально розроблений фармкомплекс. Ефективність декомпресії оцінювали за об'ємною швидкістю виділення жовчі по дренажу, причому як оптимальний цільовий рівень прийнято величину 60-100 мл/доб., максимально прийнятна - 300 мл/доб.

Пункційні та лапароскопічно асистовані декомпресії біліарного дерева були виконані лише у 112 (41,2\%) хворих основної групи. Серед методів біліарної декомпресії віддавали перевагу черезшкірній черезпечінковій холангіостомії (ЧШЧПХС) - 44 (39,3 \%) хворих, проте у випадках технічних труднощів (наприклад, через варіабельну анатомію судинного русла печінки) вдавалися до діагностичної лапароскопії (це також надавало 
певну інформацію про резектабельність процесу) із холецистостомією (ЛХ) (37 хворих (33,0 \%)) або пункційної УЗ-контрольованої холецистостомії (ПХ) (31 хворих (27,7 \%)) (табл. 2).

Таблиця 2. Методи біліарної декомпресії

\begin{tabular}{||l|c||}
\hline \multicolumn{1}{|c|}{ Метод втручання } & $\begin{array}{c}\text { Кількість хворих } \\
(\mathrm{n}=112)\end{array}$ \\
\hline $\begin{array}{l}\text { Черезшкірна черезпечінкова } \\
\text { холангіостомія }\end{array}$ & $44(39,3 \%)$ \\
\hline $\begin{array}{l}\text { Лапароскопічна } \\
\text { холецистостомія }\end{array}$ & $37(33,0 \%)$ \\
\hline Пункційна холецистостомія & $31(27,7 \%)$ \\
\hline
\end{tabular}

Завдяки дотриманню застосування розробленого алгоритму детоксикації із застосуванням біліарного дренування у хворих основної групи на третій день рівень білірубінемії склав в середньому 185,1 $\pm 2,4$ мкмоль/л, тоді як на п'ятий день - вже 163,2 2 2,6 мкмоль/л і напе-

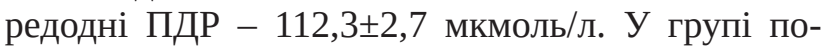
рівняння, де дотримувалися звичайного обсягу підготовки хворих до радикального операційного втручання, вихідний рівень загального білірубіну склав 270,6 4,6 мкмоль/л, на третій день $258,4 \pm 2,9$ мкмоль/л, на пятий - 222,2 $\pm 3,8$ мкмоль/л, а напередодні ПДР - 198,3ะ3,3 мкмоль/л (рис. 1).

Таким чином, в основній групі після декомпресії декремент рівня загального білірубіну склав $\Delta=-59,1$. Натомість у групі порівняння напередодні ПДР декремент рівня загального білірубіну

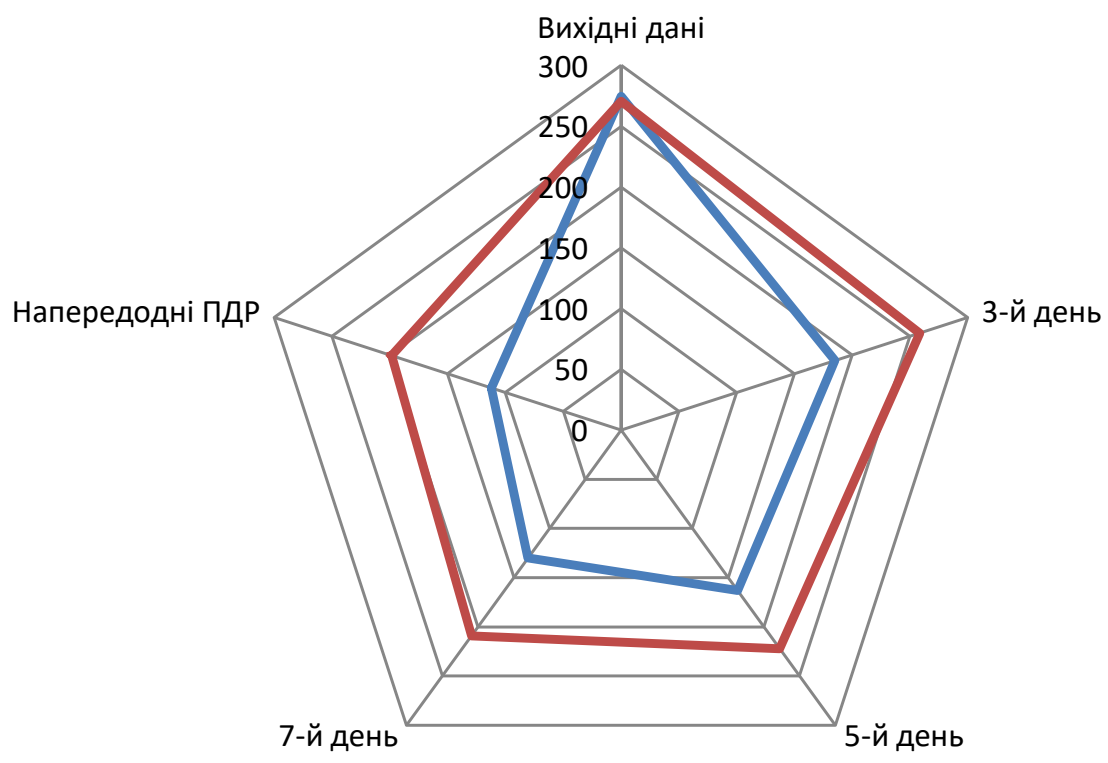

Основна група
Група порівняння

Рис. 1. Динаміка загального білірубіну в групах спостереження.

склав $\Delta=-26,7$. Після виконання ПДР декремент білірубінемії в обох групах не перевищував 40 \% й склав в основній групі $32,7 \pm 2,8 \%$, а у групі контролю - 27,4 $41,6 \%$.

При порівнянні клінічної ефективності різних методів біліарної декомпресії в аспекті підготовки хворого до операційного втучання отримано такі результати.

3 представленої таблиці видно, що на перший день після операційного втручання статистично значущі відмінності між різними методами декомпресії були відсутні. Так, у хворих, яким виконували черезшкірну черезпечінкову холангіостомію, вміст загального білірубіну складав 296 \pm 13 мкмоль/л, при застосуванні лапароскопічної холецистостомії (ЛХ) - 308 \pm 19 мкмоль/л, а при пункційній холецистостомії (ПХ) - 301士14 мкмоль/л. В усіх підгрупах з початку 3-го дня спостерігалося зниження концентрації білірубіну, більш виражене у пацієнтів, яким виконували ЧШЧПХС (164 \pm 18 мкмоль/л, $\mathrm{p}<0,05)$. В середньому на 9 добу визначали достовірне зниження показників загального білірубіну після ЧШЧПХС на 41,2 \%, після ЛХ - на 13,6 \% та після ПХ - на 6,6 \% (р<0,05) (табл. 3).

Після передопераційної підготовки хворим виконували радикальне операційне втручання в 


\section{З ДОСВІДУ РОБОТИ}

Таблиця 3. Динаміка загального білірубіну

\begin{tabular}{||l|c|c|c|c|c||}
\hline \multicolumn{1}{|c|}{ Метод декомпресії } & 1 -й день & 3-й день & 5-й день & 7 -й день & 9 -й день \\
\hline $\begin{array}{l}\text { Черезшкірна } \\
\text { черезпечінкова } \\
\text { холангіостомія }\end{array}$ & $296 \pm 13$ & $226 \pm 16$ & $220 \pm 22$ & $202 \pm 19 *$ & $164 \pm 18^{*}$ \\
\hline $\begin{array}{l}\text { Лапароскопічна } \\
\text { холецистостомія }\end{array}$ & $308 \pm 19$ & $302 \pm 21$ & $295 \pm 23$ & $290 \pm 22$ & $266 \pm 23^{*}$ \\
\hline $\begin{array}{l}\text { Пункційна } \\
\text { холецистостомія }\end{array}$ & $301 \pm 14$ & $297 \pm 14$ & $289 \pm 18$ & $293 \pm 24$ & $281 \pm 18^{*}$ \\
\hline \hline
\end{tabular}

Примітка. ${ }^{*}-\mathrm{p}<0,05$.

обсязі ПДР у різних модифікаціях щодо способу накладення панкреатодигестивного анастомозу (ПДА). Післяопераційна летальність в основній групі склала 6,3 \%, а в групі порівняння - 11,9 \%.

Висновки. Серед методів біліарної декомпреciї у хворих із механічною жовтяницею різного генезу ЧШЧПХС порівняно з ЛХ та ПХ супроводжується швидшим відновленням когнітивних функцій, загального стану хворого в цілому та, зокрема, функціонального стану печінки. Впродовж

\section{СПИСОК ЛІТЕРАТУРИ}

1. Копчак В. М. Рак підшлункової залози: українські та світові тенденції / В. М. Копчак, Ю. І. Зайвелєва // Практична онкологія. (online). - 2020. - Том 3, № 1. - C. 42-45.

2. Досвід лікування хворих із пухлинами панкреатодуоденальної зони / О. Б. Кутовий та співавт. // Клінічна хірургія. - 2018. - № 6 (2). - С. 49-51.

3. Современные аспекты хирургического лечения синдрома механической желтухи / В. Ю. Михайличенко, В. В. Кисляков, А. М. Резниченко и соавт. // Современные проблемы науки и образования. - 2019. - № 3. - С. 78-83.

4. Каніковський О. Є. Алгоритм хірургічного лікування ускладнених форм хронічного панкреатиту / О. Є. Каніковський, І. В. Павлик, І. В. Олійник // Медичні перспективи. 2018. - Т 23, № 4. - C. 79-84.

5. Fekaj E. Obstructive jaundice / E. Fekaj, N. Jankulovski, N. Matveeva // Austin Dig. Syst. - 2017. - Vol. 2 (1). - CP. 1006. 6. Хірургічне лікування раку підшлункової залози та периампулярної зони (стратегічні та тактичні питання) / В. В. Бойко, І. А. Криворучко, Є. В. Мушенко, Р. М. Смачило.

\section{REFERENCES}

1. Kopchak, V.M., \& Zaivelieva, Yu.I. (2020). Rak pidshlunkovoi zalozy: ukrainski ta svitovi tendentsii [Pancreatic cancer: Ukrainian and worldwide tendencies]. Praktychna onkolohiia
9 діб передопераційної підготовки воно проявляється достовірним більш суттєвим зниженням показників загального та прямого білірубіну, лужної фосфатази та ГГТ відповідно на 41,2\%, 43,5%, $58,5 \%$ та 52,1 \% на тлі проведення ЧШЧПХС ( $<0,05)$. Ефективність порівняних методів декомпресії зменшується від 94 \% (ЧШЧПХС) та 89 \% (ЛХ) до 76 \% (ПХ) (p<0,05).

Застосування розробленого алгоритму профілактики періопераційних ускладнень дає змогу достовірно зменшити летальність з 19 (11,9 \%) до 7 (6,3\%).

- Харків : Промінь, 2019. - 160 с.

7. Мультимодальная программа ускоренного восстановления при панкреатодуоденальной резекции / А. Ю.Усенко, А. В. Скумс, Р. А. Шеламова, В. А. Гнжа // Хирургия. Восточная Европа. - 2018. - Т 7, № 1. - С. 33-44.

8. Ярешко В. Г. Хирургическое лечение рака поджелудочной железы / В. Г. Ярешко, К. Н. Отарашвили // Харківська хірургічна школа. - 2015. - № 4 (73). - С. 75-79.

9. Pavlidis E. T. Pathophysiological consequences of obstructive jaundice and perioperative management / E. T. Pavlidis, T. E. Pavlidis // Hepatobiliary \& Pancreatic Diseases International. - 2018. - Vol. 17. - P. 17-21. - Access mode : https://doi. org/10.1016/j.hbpd.2018.01.008

10. Миниинвазивные методы декомпрессии в лечении механической желтухи злокачественного генеза у пациентов пожилого и старческого возраста / М. Ю. Кабанов, И. А. Соловьев, Д. М. Яковлева и соавт. // Вестник Национального медико-хирургического Центра им. Н. И. Пирогова. - 2018. - № 13. - С. 74-78. 


\title{
З ДОСВІДУ РОБОТИ
}

of patients with tumors of the pancreatoduodenal area]. Klinichna khirurhiia - Clinical Surgery, 6 (2), 49-51 [in Ukrainian].

3. Mihajlichenko, V.Ju., Kisljakov, V.V., \& Reznichenko, A.M. (2019). Sovremennye aspekty hirurgicheskogo lecheniya sindroma mehanicheskoy zheltuhi [Modern aspects of the mechanical jaundice syndrome surgical treatment]. Sovremennye problemy nauki i obrazovaniya - Modern Aspects of Science and Education, 3, 78-83 [in Russian].

4. Kanikovskyi, O.Ye., Pavlyk, I.V., \& Oliinyk, I.V. (2018). Alhorytm khirurhichnoho likuvannia uskladnenykh form khronichnoho pankreatytu [Algorithm of complicated chronic pancreatitis surgical treatment]. Medychni perspektyvy - Medical Perspectives, 23 (4), 79-84 [in Ukrainian].

5. Fekaj, E., Jankulovski, N., \& Matveeva, N. (2017). Obstructive jaundice. Austin Dig. Syst., 2 (1), 1006.

6. Boiko, V.V., Kryvoruchko, I.A., Mushenko, Ye.V., \& Smachylo, R.M. (2019). Khirurhichne likuvannia raku pidshlunkovoi zalozy ta peryampuliarnoi zony(stratehichni ta taktychni pytannia) [Surgical treatment of pancreatic and periampular cancer (strategic and tactical questions)]. Kharkiv: Promin [in Ukrainian].
7. Usenko, A.Yu., Skums, A.V., Shelamova, R.A., \& Hnzha, V.A. (2018). Multymodalnaia prohramma uskorennoho vosstanovlenyia pry pankreatoduodenalnoi rezektsii [The multimodal programme of accelerated recovery after pancreatoduodenal resection]. Khirurgiya. Vostochnaya Yevropa - Surgery. Eastern Europe, (1), 33-44 [in Russian].

8. Yareshko, V.H., \& Otarashvyly, K.N. (2015). Khirurhicheskoe lechenye raka podzheludochnoy zhelezy [Surgical treatment of pancreatic cancer]. Kharkivska khirurhichna shkola - Kharkiv Surgical School, 4 (73), 75-79 [in Russian].

9. Pavlidis, E.T. (2018). Pathophysiological consequences of obstructive jaundice and perioperative management. Hepatobiliary \& Pancreatic Diseases International, 17, 17-21.

10. Kabanov, M.Yu. (2018). Miniinvazivnye metody dekompressii $\mathrm{v}$ lechenii mekhanycheskoy zheltukhy zlokachestvennogo geneza u patsyentov pozhylogo i starcheskogo vozrasta [Minimally invasive methods of decompression in the treatment of obstructive jaundice of malignant genesis in elderly and senile patients]. Vestnyk Natsyonalnogo medyko-khirurgicheskogo Tssentra im. N.Y. Pyrogova - N.I. Pirogov National Medico-Surgical Center's Bulletin, 13, 74-78 [in Russian].

Отримано 16.06.2021

Електронна адреса для листування: gemostatik@gmail.com

\author{
P. T. MURAVIOV ${ }^{1,2}$, B. S. ZAPOROZHCHENKO ${ }^{1,2}$, I. E. BORODAEV ${ }^{1,2}$, HARHOURI MAKREM $^{1}$
}

Odesa National Medical University ${ }^{1}$

MUI "ORCMC" OF THE ODESA REGIONAL COUNCIL²

\section{THE PREOPERATIVE PREPARATION PECULIARITIES OF PATIENTS WITH FOCAL DISEASES OF THE BILOPANCREATICODUODENAL ZONE, COMPLICATED BY MECHANICAL JAUNDICE}

\begin{abstract}
The aim of the work: to compare the effectiveness of existing methods of jaundiced patients with focal diseases of the biliopancreatoduodenal zone preparing to the pancreatoduodenal resection performing, and to determine the effectiveness of the applied methods of biliary decompression.

Materials and Methods. The results of surgical treatment of 272 patients who underwent pancreatoduodenal resection in various modifications for focal diseases of the biliopancreatoduodenal zone complicated by the development of obstructive jaundice syndrome were analyzed. The main group included 112 patients, who were prepared for surgery and predicted the course of the postoperative period according to the developed algorithm. The comparison group included 160 patients, who were prepared only in a conservative way.

Results and Discussion. Due to the application of the developed detoxification algorithm with the use of biliary decompression in patients of the main group on the third day, the level of bilirubinemia averaged $(185.1 \pm 2.4) \mu \mathrm{mol} / \mathrm{L}$, while on the fifth day it was already $(163.2 \pm 2.6) \mu \mathrm{mol} / \mathrm{L}$ and on the eve of pancreatoduodenal resection - (112.3 \pm 2.7$) \mu \mathrm{mol} / \mathrm{L}$. In the comparison group, where the preparation of patients for radical surgery was carried out only by conservative measures without biliary drainage, the initial level of total bilirubin was $(270.6 \pm 4.6) \mu \mathrm{mol} / \mathrm{L}$, on the third day $-(258.4 \pm 2.9) \mu \mathrm{mol} / \mathrm{L}$, on the fifth $-(222.2 \pm 3.8) \mu \mathrm{mol} / \mathrm{L}$, and on the eve of pancreatoduodenal resection - (198.3 \pm 3.3$) \mu \mathrm{mol} / \mathrm{L}$. Thus, in the main group after decompression, the decrement of the total bilirubin level was $\Delta=-59.1$. But in the comparison group on the eve of pancreatoduodenal resection, the decrement of the total bilirubin level was $\Delta=-26.7$. After pancreatoduodenal resection performing, the decrement of bilirubinemia in both groups did not exceed $40 \%$ and was (32.7 \pm 2.8$) \%$ in the main group, and (27.4 \pm 1.6$) \%$ in the control group. When comparing measures for the correction of biliary hypertension in patients of the main group, in all subgroups, starting from the 3rd day, a gradual decrease in the concentration of bilirubin was observed, more expressed in patients who underwent percutaneous transhepatic cholangiostomy $(164 \pm 18 \mu \mathrm{mol} / \mathrm{L}, \mathrm{p}<0.05)$. On average, on day 9 , a significant decrease in total bilirubin parameters was determined after percutaneous transhepatic cholangiostomy by $41.2 \%$, laparoscopic cholecystostomy by $13.6 \%$ and after puncture cholecystostomy by $6.6 \%(\mathrm{p}<0.05)$.
\end{abstract}

Key words: obstructive jaundice; biliary drainage; pancreatoduodenal resection; chronic pancreatitis; pancreatic cancer. 